\title{
Optical Mapping
}

National Cancer Institute

\section{Source}

National Cancer Institute. Optical Mapping. NCI Thesaurus. Code C116162.

A technique used for constructing the ordered and high-resolution genome or

chromosome sized restriction enzyme map of an org anism from a single, stained DNA

molecule, digested by the restriction enzyme and imaged by an optical microscope. 